\title{
DO MICROFINANCE PROGRAMS HELP FAMILIES INSURE CONSUMPTION AGAINST ILLNESS?
}

\author{
PAUL GERTLER ${ }^{\mathrm{a}, *}$, DAVID I. LEVINE ${ }^{\mathrm{a}}$ and ENRICO MORETTI ${ }^{\mathrm{b}}$ \\ ${ }^{\mathrm{a}}$ Haas School of Business, University of California, Berkeley, CA, USA \\ ${ }^{\mathrm{b}}$ Department of Economics, University of California, Berkeley, CA, USA
}

\begin{abstract}
SUMMARY
Families in developing countries face enormous financial risks from major illness both in terms of the cost of medical care and the loss in income associated with reduced labor supply and productivity. We test whether access to microfinancial savings and lending institutions helps Indonesian families smooth consumption after declines in adult health. In general, results support the importance of these institutions in helping families to self-insure consumption against health shocks. Copyright (C) 2008 John Wiley \& Sons, Ltd.
\end{abstract}

Received 7 March 2007; Revised 16 November 2007; Accepted 13 March 2008

JEL classification: O120; O160; E210

KEY WORDS: microfinance; consumption smoothing; Indonesia

Families in developing countries face enormous financial risks from major illness in terms of both the cost of medical care and the loss of income associated with reduced labor supply and productivity. Because of holes in public social safety nets and the lack of formal insurance markets in developing countries, families are forced to rely on private, informal insurance mechanisms. ${ }^{1}$ However, recent evidence suggests that families relying solely on informal mechanisms are not very well able to insure consumption over periods of major illness (Gertler and Gruber, 2002). ${ }^{2}$

Financial savings and other assets, thus, often play a key role in self-insuring families' consumption against health crises. One promising strategy to help families insure consumption is to make saving more convenient and improve access to credit (Morduch, 1999; note we use 'insurance' to include what is commonly called 'self-insurance' by running down assets). Indeed, savings play a major role in insuring consumption in life cycle theories (Deaton, 1992). Empirically, Gertler and Gruber (2002) show that Indonesian families with more assets are better able to insure consumption against major illness. More generally, Jalan and Ravallion (1999) find that wealthier Chinese households are better able to insure consumption against income shocks. In addition, studies from India (Rosenzweig and Wolpin, 1993) and West Africa (Fafchamps et al., 1998) suggest that sales of livestock help insure consumption. The research team at IFPRI has a number of studies on consumption smoothing (e.g. Harrower and Hoddinott, 2004; Hanan and Skoufias 1997, 1998; Skoufias and Quisumbing, 2005). While there is some variation across countries, overall they find that many households cannot insure or self-insure all shocks to income. As in our results, those with low assets have the hardest time self-insuring consumption.

\footnotetext{
*Correspondence to: Haas School of Business, University of California, Berkeley, CA 94720-1900, USA.

E-mail: gertler@haas.berkeley.edu

${ }^{1}$ See Morduch $([1995,1999)$ for reviews of the consumption-insuring literature.

${ }^{2}$ In fact, Cochrane (1991) shows that households in the United States are not able to fully insure consumption against major illness.
} 
Unfortunately, commercial financial institutions in developing countries are weak and do not adequately service the poor. These institutions are typically not conveniently located, require substantial collateral for loans, and impose relatively large costs on small savings accounts. In addition, nonfinancial savings mechanisms often involve substantial risks (for example, farm animals can get sick) and high transaction costs (for example, from pawning jewelry).

In contrast, microfinance programs such as the Grameen Bank in Bangladesh, BancoSol in Bolivia, and Bank Rakyat in Indonesia hold substantial promise (Morduch, 1999). These programs are typically targeted at the poor and near poor, have alternatives to collateral for loans (such as group lending and peer monitoring), actively promote savings, and provide a safe low cost haven for savings.

In this paper, we examine the roles of both large commercial and microfinance institutions in helping families insure consumption against major illness in Indonesia, a developing country with financial features of special interest for this analysis. From the end of the 1960s until the 1997 financial crisis, Indonesia's real per annual capita growth rate has been an impressive 3.9\%. Even after this growth, per capita incomes were still only \$US 880 per year in 1996 (Asian Development Bank, 1997). Moreover, few individuals are covered by health insurance other than the implicit insurance provided through the almost free but low-quality public health-care system. Disability insurance is almost nonexistent.

We begin this paper by testing whether Indonesian households are able to insure consumption against major illness shocks. Previous work has had mixed results, with the smallest reductions in consumption tending to follow declines in self-reported morbidity. For example, Townsend (1994) has found that the percentage of the year that an adult male is sick has no effect on consumption. Kochar (1995) has modeled wage income and informal borrowing as a function of illness in the family, as measured by a member of the family experiencing a loss of work due to illness. She finds that illness to the male lowers wage income and increases informal borrowing during peak periods in the agricultural cycle, but that there are no effects during slack periods and no effects of female illnesses.

A key limitation of past work, however, is that the measures of health employed may reflect only small, and even potentially anticipated, changes in health status, not the kind of large unexpected major illnesses that may be difficult to insure. Even if families are able to insure frequent small illness shocks, they may not be able to insure the rare large shocks. This would imply that it is important to use measures of more severe illness in fully assessing the ability of households to insure consumption.

We address the potential shortcomings of previous work in this area by using measures of individuals' physical abilities to perform activities of daily living (ADLs) such as bending and walking $5 \mathrm{~km}$. ADLs have been proven to be reliable and valid measures of physical functioning ability in both developed and developing countries, and they distinguish the type of serious exogenous health problems that are likely to be correlated with changes in labor market and consumption opportunities (Stewert et al., 1990; Strauss et al., 1993). We find that families are only able to insure about $40 \%$ of the costs of a major illness. This estimate is remarkably close to estimates in Gertler and Gruber (2002) based on a different data set.

The reduction in consumption could be due to an inability to insure the costs of illness. Alternatively, consumption may decline because the household's utility from consumption is lower when health declines (a hypothesis called 'state-dependent utility') or because lower consumption causes the worse health. We perform a number of tests of these alternative hypotheses and find no support for them.

Having shown that many Indonesian households are unable to fully insure consumption against major illness shocks, we turn to the relationship between access to credit and consumption smoothing. In particular, we estimate the effect of geographical proximity to financial institutions on consumption smoothing.

An important difficulty in estimating the effect of credit availability on consumption smoothing is that private profit-maximizing credit institutions are likely to be located in prosperous areas, making it difficult to interpret the estimated correlations. Because we use longitudinal data, we can control for many potential sources of heterogeneity across households. In particular, by observing the same 
household in two moments in time, we can abstract from all permanent characteristics of the households that may affect ability to smooth consumption and induce spurious correlation. We also control for a rich set of observable time-varying characteristics of households. Identification comes from the comparison of the difference in consumption levels before and after a major health shock for households who live close to financial institutions and households who live far from financial institutions.

Our main result is that households that are closer to financial intuitions are better able to insure consumption. Moreover, we use data on the location of branches of both private banks and Indonesia's most important microfinance institution, Bank Rakyat Indonesia (BRI, specifically the village banks or BRI-UD), to test whether the effect on consumption smoothing is different. By 1996, over 16 million households (one-sixth of all households) had a savings account with BRI. We find that the estimated effect of being close to a BRI branch is similar to the estimated effect of being close to a commercial bank; we note that private banks target prosperous population, while BRI targets less prosperous populations. Therefore, the finding that the estimated effect of geographical proximity is similar for private institutions and BRI lends further credibility to our assumption that location is not correlated with unobservables, after conditioning on our rich set of controls.

We conclude that government promotion of microfinance and microsaving programs can be useful in helping families cope with major health shocks, especially in areas where private credit is not available.

The remainder of the paper is organized as follows. In the next section we describe our basic empirical specification, the ADL index, and report estimates of a simple model of consumption and health. In Section 2 we report the results of several state dependency tests. In Section 3 we report estimates of the effect of geographical proximity to financial institutions on consumption smoothing. Concluding remarks and policy implications are in Section 4.

\section{HEALTH AND CONSUMPTION}

\subsection{Empirical specification}

In this section, we test whether households are insuring consumption against unexpected costs of illness. If we assume that health shocks do not change the marginal utility of consumption (an assumption we return to below), several theories predict that health shocks will leave consumption unchanged. First, the theory of full insurance models consumption insurance in terms of interhousehold risk sharing (e.g. Cochrane, 1991; Deaton, 1994; Townsend, 1994; Attanasio and Ríos-Rull, 2000). The key empirical insight into the theory of full insurance is that the growth in each household's consumption will not depend on changes in household resources that are uncorrelated with shifts in preferences once the growth in community resources has been taken into account. Second, the life cycle hypothesis with precautionary savings examines self-insurance through reducing savings and (during temporary disability) increasing borrowing. Empirically, the predictions are quite similar, so we can test both sets of theories by estimating how health shocks affect per capita consumption:

$$
\Delta \ln \left(\frac{C_{i j}}{n_{i j}}\right)=\alpha_{j}+\beta \Delta h_{i j}+\sum_{k} \lambda_{k} X_{i j k}+\epsilon_{i j}
$$

which is a regression of the growth in log per capita (nonmedical care) consumption for household $i$ in community $j$ against community fixed effects $\left(\alpha_{j}\right)$, the change in health $\left(\Delta h_{i j}\right)$, a series of demographic controls $\left(X_{i j k}\right)$, and a random error $\left(\varepsilon_{i j}\right)$. In short, Equation (1) regresses changes in consumption per capita against the change in health. We include demographic controls to capture other secular trends: the husband's and wife's age and education, and the change in log family size and family structure. If there is full insurance of illness, then there will be no effect of the change in health on the change in consumption, implying $\beta=0$. 
The model examines how changes in health affect changes in consumption and as such, controls for fixed and unobserved factors such as high educational quality or advantaged family background that might make a family have both high consumption and good health. We also include dummies for province interacted with rural versus urban to capture local differences in regional price inflation, weather, and so forth.

A major assumption of the full-insurance interpretation, however, is that reductions in health do not affect the marginal utility of consumption or leisure. If this is not true, then even with full insurance, the growth of consumption will vary with the state of health. That is, in the formulation above, $\Delta h_{i j}$ will be correlated with omitted preferences and thereby with the error term, biasing the estimated coefficient $\beta$ in Equation (1). An important feature of our empirical strategy is to test for such changes in preferences. As we discuss in detail later, we find no evidence that state dependence explains our empirical results.

Idiosyncratic changes in household income that feed back into health are a related concern; for example, a bad harvest or job loss that results in a deterioration of health (perhaps through lower nutrition or mental depression). However, our empirical results, presented in detail later, suggest that this alternative explanation does not account for our findings. In particular, the finding that the effects of illness on consumption are stronger for families who are not well insured is inconsistent with an idiosyncratic shock or with reverse causality driving the results.

\subsection{Data and measurement}

We estimate the model with data from the Indonesia Family Life Surveys (IFLS). ${ }^{3}$ The IFLS is a panel survey of over 7000 households representative of $83 \%$ of the population that collected socioeconomic information including a detailed consumption module at the household level and detailed information from individuals including health status measures. In addition, village officials were surveyed regarding local institutions including availability of commercial banks and microfinance programs.

The IFLS interviewed households in 1993 and again in 1997. Our sample includes all households with nonmissing variables with a husband under age 60 and a wife. Overall the IFLS had only $6 \%$ attrition of households, which is a very low rate for longitudinal household surveys (Thomas et al., 2001). We matched 6742 of the 7224 households in the 1993 to 1997 data.

Raw self-reported consumption data appear rather noisy. In order to minimize measurement error in consumption, we trim the bottom and top $1 \%$ of consumption levels in 1993 and 1997, and the bottom and top $1 \%$ in consumption changes between 1993 and 1997. After trimming we are left with 6353 observations. Of these, 4480 observations have nonmissing values for all the relevant variables. After dropping single-headed households and households with heads over age 60, we are left with 3281 observations. Results are similar when we included single-parent households in the sample. We did not include households with household heads over age 60 because we feared older household heads might have lower contributions to the household's income, so disabilities might be both more common and less important.

The dependent variable for our analysis is the change in the log of monthly nonmedical consumption per capita. The IFLS measured consumption using a 57-item questionnaire covering both expenditures and the value of home-produced consumption for a comprehensive list of food and nonfood consumption items. It is important to examine nonmedical consumption as a new disability may increase medical costs and effective implicit or explicit insurance should smooth nonmedical consumption.

Consumption is in nominal per capita terms. However, we account for location-specific differences in inflation rates by including a separate intercept for the rural and the urban areas of each province. The means for consumption expenditures and other household variables are in Table I.

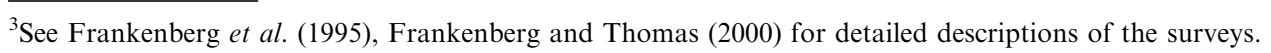


Table I. Means and standard deviations of $(\mathrm{A})$ household level variables $(N=3281)$ and $(\mathrm{B})$ characteristics of head and spouse $(N=3281)$

\begin{tabular}{|c|c|c|c|}
\hline Monthly household total consumption per capita (Rupiah) & $\begin{array}{c}1993 \\
52372 \\
(43605)\end{array}$ & $\begin{array}{c}1997 \\
84143 \\
(69059)\end{array}$ & $\begin{array}{c}\text { Change } \\
31771 \\
(55433)\end{array}$ \\
\hline
\end{tabular}

(A)

Monthly household total consumption per capita (real 1993

Rupiah, using Asia Development Bank's urban CPI series, derived from BPS data)

Assets (Rupiah)

Savings account $(=1)$

Number of household members

Proportion of members male age $0-5$

Proportion of members male age 6-17

Proportion of members male age 18-49

Proportion of members male age $50+$

Proportion of members female age $0-5$

Proportion of members female age 6-17

Proportion of members female age 18-49

Proportion of members female age $50+$

Household is in rural area

(B) Male head of household

ADL index

Proportion reporting any ADL limitation

Proportion reporting increase in ADL index

Proportion reporting decrease in ADL index

Predicted hourly wage rate (Rupiah)

Age

Not completed primary schooling $(=1)$

Completed primary school $(=1)$

Completed junior high school $(=1)$

Completed senior high school $(=1)$

Some college $(=1)$

Female head of household

ADL index

Proportion reporting any ADL limitation

Proportion reporting increase in ADL index

Proportion reporting decrease in ADL index

Predicted hourly wage rate (Rupiah)
52372

(43 605)

2781946

(7393 346)

0.245

$(0.430)$

5.024

(1.910)

0.075

(0.120)

0.140

(0.156)

0.227

(0.129)

0.059

(0.114)

0.071

(0.118)

0.136

(0.153)

0.241

(0.118)

0.048

(0.106)

0.564

0.986

(0.097)

0.076

(0.266)

6.483

(0.451)

40.38

(9.831)

0.108

0.552

0.130

0.163

0.047

0.962

(0.122)

0.168

(0.374)

5.912

(0.487)
64609

$(53027)$
5020260
$(11094098)$
0.252
$(0.435)$
5.647
$(2.088)$
0.052
$(0.096)$
0.140
$(0.148)$
0.235
$(0.133)$
0.067
$(0.109)$
0.050
$(0.096)$
0.139
$(0.145)$
0.249
$(0.125)$
0.054
$(0.105)$
0.574

0.981
$(0.096)$
0.141
$(0.348)$

$+23 \%$

2235111

(10 529372)

0.007

(0.506)

0.623

(0.915)

$-0.022$

$(0.117)$

0.000

(0.137)

0.008

(0.116)

0.008

(0.068)

$-0.021$

(0.117)

0.002

$(0.136)$

0.008

(0.111)

0.006

(0.069)

0.049

(0.107)

$-0.010$

(0.127)

0.064

$(0.382)$

0.053

$(0.225)$

0.123

(0.328)

0.936

(0.117)

0.347

(0.476)

$-0.026$

(0.161)

0.179

(0.562)

0.111

(0.315)

0.294

(0.455) 
Table I. Continued.

\begin{tabular}{|c|c|c|c|}
\hline Monthly household total consumption per capita (Rupiah) & $\begin{array}{c}1993 \\
52372 \\
(43605)\end{array}$ & $\begin{array}{c}1997 \\
84143 \\
(69059)\end{array}$ & $\begin{array}{c}\text { Change } \\
31771 \\
(55433)\end{array}$ \\
\hline Age & $\begin{array}{l}35.27 \\
(9.373)\end{array}$ & - & - \\
\hline Not completed primary schooling $(=1)$ & 0.191 & - & - \\
\hline Completed primary school $(=1)$ & 0.558 & - & - \\
\hline Completed junior high school $(=1)$ & 0.122 & - & - \\
\hline Completed senior high school $(=1)$ & 0.111 & - & - \\
\hline Some college $(=1)$ & 0.018 & - & - \\
\hline
\end{tabular}

The key independent variable is the change in health, measured by an index of an individual's selfreported ability to physically perform ADLs. These physical functioning measures are based on individuals' self-ratings of ability to carry a heavy load for $20 \mathrm{~m}$; sweep the floor or yard; walk for $5 \mathrm{~km}$; take water from a well; and bend, kneel, or stoop. The responses to these questions on the survey were coded either as can do it easily (a value of 1), can do it with difficulty (3), and unable to do it (5).

The specific ADL questions in the IFLS survey were adapted from standard US measures after extensive testing and modification to ensure that questions fit the local cultural context. To minimize measurement error, every adult in the household was interviewed directly and proxy responses were not accepted.

These self-reported physical functioning measures have been tested extensively for reliability (consistency across repeated interviews and interviewers) and validity (consistency between ADL reports and other assessments of physical capabilities; e.g. Andrews et al., 1986; Guralnik et al., 1989; Ju and Jones, 1989; Strauss et al., 1993; Ware et al., 1980).

We summed the several ADL self-reports into a single score and normalized it using a standard formula (from Stewert et al., 1990):

$$
\mathrm{ADL} \mathrm{Index}_{i}=\frac{\text { Score }_{i}-\text { Minumum Score }}{\text { Maximum Score }- \text { Minumum Score }}
$$

The ADL index takes on a value of 1 if the individual can perform all ADLs without difficulty and 0 if the individual cannot perform any ADLs. If an individual in 1993 had no difficulty in performing all the ADLs and fully loses the capacity to perform one of the five ADL by 1997, the decline in the ADL index would be -0.2 .

The means and standard deviations of the health outcome measures for the husband and wife are in Table I. On average, in our sample, the mean ADL index for the male heads of household is 0.986 in 1993 and 0.981 in 1997 out of a possible 1. The corresponding figures for female heads of household are 0.962 and 0.936 .

Many respondents report changes in health status between 1993 and 1997. Figure 1 pictures the distribution of the nonzero changes in the ADL indices. Health appears to be declining in this sample. The percentage of male heads of household who report an improvement in ADLs is $5 \%$, while the percentage who reports a decline is $12 \%$. The health decline with age is more pronounced for female heads of household, for whom $11 \%$ report an improvement and $29 \%$ report a decline.

Even when severe, changes in ADLs are usually not permanent. Of those reporting limited ADLs in 1993, two-thirds had partial or complete recovery by 1997. This pattern reflects both the fact that we examine only prime-age adults and the high rates of accidents and infectious diseases (as opposed to cancer, coronary heart disease, and other chronic conditions that lead to a higher share of disabilities in rich nations). As a result, it is not surprising that people usually recover from basic limitations; that is, 


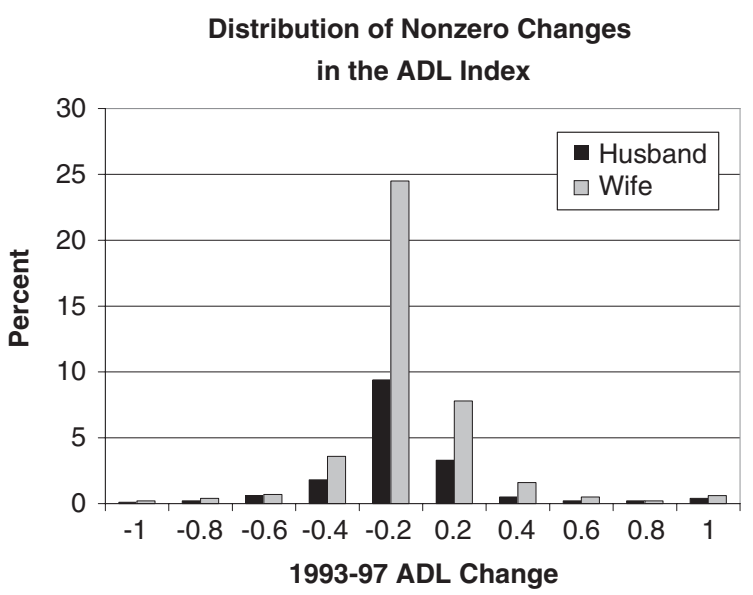

Figure 1. Distribution of nonzero changes in the ADL index

we primarily measure severe temporary changes in health as opposed to permanent deterioration. This result is confirmed by the fact that effects are similar when we examine only decreases in the ADL index.

Although the ADL index is a more objective measure of health status than self-reported symptoms (see Gertler and Gruber, 2002), it still contains subjective judgment. Fortunately, identification of the econometric models in this paper comes from changes in ADL between 1993 and 1997. To the extent that the subjective component in an individual's assessment of his or her physical capabilities is constant between 1993 and 1997, it is differenced out in our analysis.

In addition to the ADL index, we control for preference shifts associated with changes in family size or structure by including the change in log family size and a series of measures of the change in the share of the family that is male and female in age groups $0-5,6-17,18-49$, and 50 plus. (Results were unchanged when we did not include these controls.) As noted above, we also control for other potential taste shifters that might be correlated with illness: the head's gender, age, education, and marital status, and the wife's age and education.

\subsection{Results}

Baseline results using health changes to predict changes in per capita consumption are in Table II. Model 1 replicates the basic model in Gertler and Gruber (2002), which uses the whole sample including households with single heads and heads over 60 years old. Gertler and Gruber estimate this model on a different Indonesian data set from 1991 to 1993. They estimate a coefficient on the change in the head's ADL index of 0.195 , which is close to our estimate of 0.165 .

Model 2 replicates this specification using our sample, which excludes single-headed households and households where the head is more than 60 years old. The coefficient on the change in the husband's ADLs increases slightly to 0.199 (difference from Model 1 not significant). The increase in the coefficient reflects the fact that by placing a limit on the age range, we are focusing on younger heads that are more likely to be working and therefore lose more income when they become ill.

Finally, the last model reported in Table II adds the change in the wife's ADL index. Here, the coefficient on the change in the husband's ADL index increases to 0.219 and the coefficient on the change in the wife's ADL index is somewhat lower at 0.172. This gap is consistent with the fact that in Indonesia the males work more hours for pay and command a higher wage rate than do females. Therefore, a husband's illness represents a larger loss of income than when the wife experiences the same illness. An illness that reduces the ADL index by one partial limitation to the husband reduces 
Table II. Regressions of change in log household per capita consumption

\begin{tabular}{|c|c|c|c|}
\hline \multirow{4}{*}{$\Delta$ in husband's ADL index } & Model 1 & Model 2 & Model 3 \\
\hline & Sample as in Gertler and Gruber (2002) & \multicolumn{2}{|c|}{$\begin{array}{l}\text { Our sample: exclude single-adult households } \\
\text { and those with head over } 60\end{array}$} \\
\hline & 0.165 & 0.199 & 0.219 \\
\hline & $(0.053)$ & $(0.078)$ & $(0.085)$ \\
\hline$\Delta$ in wife's ADL index & - & - & $\begin{array}{c}0.172 \\
(0.064)\end{array}$ \\
\hline Head is female $(=1)$ & $\begin{array}{r}-0.009 \\
(0.866)\end{array}$ & $\begin{array}{c}0.043 \\
(0.228)\end{array}$ & $\begin{array}{c}0.723 \\
(0.589)\end{array}$ \\
\hline Head's age & $\begin{array}{r}-0.019 \\
(0.004)\end{array}$ & $\begin{array}{r}-0.016 \\
(0.012)\end{array}$ & $\begin{array}{r}-0.016 \\
(0.012)\end{array}$ \\
\hline Head not completed primary school & $\begin{array}{r}-0.032 \\
(0.026)\end{array}$ & $\begin{array}{l}0.049 \\
(0.034)\end{array}$ & $\begin{array}{l}0.025 \\
(0.037)\end{array}$ \\
\hline Head completed primary school & $\begin{array}{c}-0.072 \\
(0.037)\end{array}$ & $\begin{array}{c}0.025 \\
(0.045)\end{array}$ & $\begin{array}{c}0.043 \\
(0.048)\end{array}$ \\
\hline Head completed junior high & $\begin{array}{r}-0.072 \\
(0.039)\end{array}$ & $\begin{array}{c}0.019 \\
(0.047)\end{array}$ & $\begin{array}{c}0.013 \\
(0.049)\end{array}$ \\
\hline Head completed senior high & $\begin{array}{r}-0.097 \\
(0.056)\end{array}$ & $\begin{array}{c}0.003 \\
(0.065)\end{array}$ & $\begin{array}{c}0.031 \\
(0.069)\end{array}$ \\
\hline Spouse's age & $\begin{array}{c}0.003 \\
(0.003)\end{array}$ & $\begin{array}{r}-0.003 \\
(0.010)\end{array}$ & $\begin{array}{r}-0.007 \\
(0.011)\end{array}$ \\
\hline Spouse not completed primary school & $\begin{array}{c}-0.021 \\
(0.026)\end{array}$ & $\begin{array}{r}-0.073 \\
(0.029)\end{array}$ & $\begin{array}{r}-0.056 \\
(0.031)\end{array}$ \\
\hline Spouse completed primary school & $\begin{array}{c}-0.014 \\
(0.039)\end{array}$ & $\begin{array}{c}-0.063 \\
(0.043)\end{array}$ & $\begin{array}{r}-0.049 \\
(0.045)\end{array}$ \\
\hline Spouse completed junior high & $\begin{array}{c}0.017 \\
(0.045)\end{array}$ & $\begin{array}{r}-0.037 \\
(0.049)\end{array}$ & $\begin{array}{r}-0.020 \\
(0.051)\end{array}$ \\
\hline Spouse completed senior high & $\begin{array}{c}-0.015 \\
(0.082)\end{array}$ & $\begin{array}{c}-0.069 \\
(0.085)\end{array}$ & $\begin{array}{r}-0.084 \\
(0.089)\end{array}$ \\
\hline Head's age squared & $\begin{array}{c}0.0002 \\
(0.0000)\end{array}$ & $\begin{array}{c}0.0001 \\
(0.0001)\end{array}$ & $\begin{array}{c}0.0001 \\
(0.0001)\end{array}$ \\
\hline Spouse's age squared & $\begin{array}{c}-0.0000 \\
(0.0000)\end{array}$ & $\begin{array}{c}0.0000 \\
(0.0001)\end{array}$ & $\begin{array}{c}0.0001 \\
(0.0001)\end{array}$ \\
\hline$\Delta$ in $\#$ of household members & $\begin{array}{c}-0.423 \\
(0.046)\end{array}$ & $\begin{array}{c}-0.634 \\
(0.067)\end{array}$ & $\begin{array}{c}-0.660 \\
(0.071)\end{array}$ \\
\hline$\Delta$ Share of males age $0-5$ & $\begin{array}{c}0.341 \\
(0.172)\end{array}$ & $\begin{array}{c}0.586 \\
(0.213)\end{array}$ & $\begin{array}{c}0.203 \\
(0.290)\end{array}$ \\
\hline$\Delta$ Share of males age $6-17$ & $\begin{array}{c}0.607 \\
(0.159)\end{array}$ & $\begin{array}{c}0.790 \\
(0.203)\end{array}$ & $\begin{array}{c}0.403 \\
(0.284)\end{array}$ \\
\hline$\Delta$ Share of males age $18-49$ & $\begin{array}{c}0.668 \\
(0.151)\end{array}$ & $\begin{array}{c}0.909 \\
(0.197)\end{array}$ & $\begin{array}{c}0.518 \\
(0.287)\end{array}$ \\
\hline$\Delta$ Share of males age $50+$ & $\begin{array}{c}0.465 \\
(0.148)\end{array}$ & $\begin{array}{c}0.615 \\
(0.212)\end{array}$ & $\begin{array}{c}0.122 \\
(0.314)\end{array}$ \\
\hline$\Delta$ Share of females age $0-5$ & $\begin{array}{c}0.464 \\
(0.172)\end{array}$ & $\begin{array}{c}0.677 \\
(0.217)\end{array}$ & $\begin{array}{r}0.0351 \\
(0.292)\end{array}$ \\
\hline$\Delta$ Share of females age $6-17$ & $\begin{array}{c}0.625 \\
(0.158)\end{array}$ & $\begin{array}{c}0.704 \\
(0.208)\end{array}$ & $\begin{array}{c}0.384 \\
(0.285)\end{array}$ \\
\hline$\Delta$ Share of females age $18-49$ & $\begin{array}{c}0.557 \\
(0.151)\end{array}$ & $\begin{array}{c}0.609 \\
(0.204)\end{array}$ & $\begin{array}{c}0.356 \\
(0.281)\end{array}$ \\
\hline$\Delta$ Share of females age $50+$ & $\begin{array}{c}0.284 \\
(0.149)\end{array}$ & $\begin{array}{c}0.397 \\
(0.220)\end{array}$ & $\begin{array}{c}0.161 \\
(0.567)\end{array}$ \\
\hline Province* (rural or urban) fixed effects & Yes & Yes & Yes \\
\hline Within R-squared & 0.075 & 0.095 & 0.095 \\
\hline
\end{tabular}

Note: Sample size $3281 \times \times$. Standard errors in parentheses.

*Significant at the $10 \%$ level; **Significant at the $5 \%$ level.

consumption by $2.4 \%$, while the same reduction to the wife reduces consumption by $1.8 \%$. If the illness causes the husband to go from being able to perform all activities to not being able to perform any, consumption falls by $22 \%$. A similar illness to the wife reduces consumption by $17 \%$. 
The control variables show a reasonable pattern of effects. Consumption growth rates are higher for older and better-educated adults. Per capita log consumption changes fall with the change in log family size, indicating some economies of scale in consumption. There is no clear pattern to the coefficients on the changes in demographic shares, which are mostly statistically insignificant.

The fact that illnesses measured by ADL changes are very strongly associated with consumption changes suggests that they represent uninsured shocks. An alternative interpretation of our results is that when adults' health declines, their preferences may change in ways that reduce consumption. If such state dependence were important, we would expect larger effects when a person had a physically demanding job prior to the loss of ADLs, as such people have lower caloric requirements when disabled and unable to work. We also expect to see similar changes in consumption for people with initially high earnings or when the household had high assets (permitting self-insurance) as for people with low incomes or assets. In the Appendix, we test these hypotheses and consistently find no evidence of such state dependence.

\section{ACCESS TO FINANCIAL INSTITUTIONS}

In this section, we address the question of whether access to financial institutions helps families insure consumption against health shocks. Financial institutions can help in a number of ways. Indonesian families have traditionally saved with means such as cash (that can be stolen or lost), chickens (that require care), and gold jewelry (that has high transaction costs of pawning and redeeming). Thus, formal savings institutions greatly lower the transaction costs of accumulating liquid assets.

In addition, to the extent that the expected real returns are higher in savings accounts than in other assets (e.g. cash, chickens, or gold jewelry), access to financial institutions may increase assets, particularly liquid assets. Finally, financial institutions can help accumulate collateral and then finance the purchase of productive assets such as bullocks, which can be sold in times of illness.

Health shocks may be difficult to smooth using credit because few financial institutions will provide uncollateralized consumption loans, especially to individuals with whom they do not have a longestablished relationship. Even with such relationships, new infusions of credit require collateral and a credible promise to repay the loan. Serious health shocks reduce collateral directly as families maintain consumption levels when income falls. In addition, illness depreciates the stock of human capital that well-informed lenders use to select borrowers.

For these reasons, we believe that financial institutions primarily help families insure consumption by facilitating the accumulation of savings both through savings accounts and the purchase of assets. Indeed, as discussed in the previous section, there is strong evidence that families that have substantial assets and those that have a high savings to consumption ratio are substantially better able to insure consumption against illness. This is also consistent with the general literature on consumption smoothing (e.g. Jalan and Ravallion, 1999).

\subsection{Access}

In a nation whose rural areas have no ATMs, distance to the financial institution measures the value of time spent making deposits and withdrawals. Given that these institutions are only open during 'banking' hours and transportation is time-consuming, even short distances can greatly raise the cost of access to savings. Moreover, microfinance institutions such as BRI engage in community outreach programs whose effectiveness diminishes the further away one lives from the institution.

Access to financial institutions also affects the ability of households to borrow. With default risk, a lender's willingness to provide credit depends in part on the borrower's collateral and on the lender's information about the borrower's ability to repay. In less-industrialized nations such as Indonesia, formal capital markets are highly imperfect. With transaction costs and information that declines with 
the distance between the lender and borrower, the location of a bank can have a large effect on credit availability. Moreover, BRI depends on intimate knowledge of the borrower as part of its 'collateral' requirements for loans.

We evaluate the effect of distance from the household to large commercial banks and to microfinance programs. However, we focus much of our attention on the microfinance programs because they are typically targeted to segments of the population that usually do not have access to credit or savings institutions, especially the poor. Moreover, microfinance programs can be more easily introduced into poor areas by government action than the other types of institutions.

Indonesia has a number of microfinance programs that provide financial services to low-income households. The most important of these is BRI, which lends to 'better-off' poor and nonpoor households.

As do most financial institutions, BRI originally located branches in regions that were more prosperous. Over time, its management realized that all regions had sufficient potential savings to make a branch sustainable. Thus, in the period we study, BRI had opened branches in essentially all of Indonesia's several thousand subdistricts (Robinson, 2001).

BRI requires individual borrowers to put up collateral, a policy that excludes the very poorest borrowers. However, BRI has pursued a strategy of setting up many small local branches where loan officers can get to know their clients and identify good credit risks. Collateral is often defined loosely, and the staff has discretion to increase the loan size for reliable borrowers who may not be able to fully collateralize their loans. Loan officers typically start clients off with small loans and condition future larger loans on repayment rates. In 1996, BRI served 2 million borrowers with an average loan size of $\$ 1007$ and had a repayment rate of $98 \%$ (Robinson, 2002).

BRI also made savings a major part of its activities in 1986. Unlike most banks, BRI branches are common in rural areas, and BRI offers a lottery where the chances of winning rise with the level of the deposit. By 1996, over 16 million households (one-sixth of all households) had a savings account with BRI. Account balances averaged about $\$ 184$ in the time period we study (Yaron et al., 1998).

The typical level of savings for BRI customers is not trivial from an insurance point of view. From the estimates in Section 1, the effect of the head of the household going from being able to perform all ADLs to half reduces household consumption by about $11 \%$, or $\$ 17$ per month. Average BRI savings, therefore, would be able to maintain household consumption levels for most of a year.

BRI supervises another program, Bank Kredit Desa (BKD), which lends to the poorest households and does not require collateral. The scale of loans is small, averaging about \$71, and BKD had over three-quarters of a million borrowers in 1994. BKD allocates funds through village-level management commissions led by village heads. Using local commissions permits a system based on individual loans to access the local information and social enforcement mechanisms usually restricted to group-lending schemes. Thus, BKD commissions can exclude the worst risks. In addition, BKD encourages savings at BRI banks. Successful BKD borrowers graduate to larger scale loans from BRI. (For more on BKD, see Morduch, 1999: 1578 and Christen et al., 1996.)

The distribution of distance to these institutions is reported in Table III. About a third of the sample lives within $1 \mathrm{~km}$ from a commercial bank. The corresponding figure for BRI and BKD is 38 and $92 \%$, respectively.

\subsection{Access and savings}

Table IV reports the association between assets and distance to these institutions. Each row of the table reports the coefficients from a regression of the log of assets in 1997 in the first panel and the probability of having a savings account in the second panel. In both cases, the closer households are to both large commercial and microfinance programs, the more assets they have and the more likely they are to have a savings account. 
Table III. Distance from household to financial institutions

\begin{tabular}{lcccc}
\hline & \multicolumn{3}{c}{ Share of households this distance away } \\
\cline { 2 - 5 } Institution & $0-1 \mathrm{~km}$ & $2-10 \mathrm{~km}$ & $10+\mathrm{km}$ & Sample size \\
\hline Commercial Bank & 0.337 & 0.445 & 0.217 & 1,737 \\
Bank Rakyat Indonesia (BRI) & 0.386 & 0.523 & 0.090 & 3,280 \\
Bank Kredit Desa (BKD) & 0.925 & 0.065 & 0.009 & 1,125 \\
\hline
\end{tabular}

Table IV. Regressions of log assets and existence of a savings account on distance to savings/credit institutions

\begin{tabular}{|c|c|c|}
\hline & Institution is $0-1 \mathrm{~km}$ from village & Institution is $2-10 \mathrm{~km}$ from village \\
\hline \multicolumn{3}{|c|}{ Dependent variable $=\log$ assets } \\
\hline Bank Rakyat Indonesia & $\begin{array}{c}0.410 \\
(0.166)\end{array}$ & $\begin{array}{c}0.270 \\
(0.157)\end{array}$ \\
\hline Bank Kredit Desa & $\begin{array}{l}1.137 \\
(0.654)\end{array}$ & $\begin{array}{c}0.815 \\
(0.676)\end{array}$ \\
\hline Commercial Bank & $\begin{array}{c}0.170 \\
(0.156)\end{array}$ & $\begin{array}{c}0.031 \\
(0.149)\end{array}$ \\
\hline \multicolumn{3}{|c|}{ Dependent variable $=$ household has a savings account $(=1)$} \\
\hline Bank Rakyat Indonesia & $\begin{array}{c}0.114 \\
(0.028)\end{array}$ & $\begin{array}{c}0.060 \\
(0.027)\end{array}$ \\
\hline Bank Kredit Desa & $\begin{array}{l}0.167 \\
(0.141)\end{array}$ & $\begin{array}{c}0.097 \\
(0.147)\end{array}$ \\
\hline Commercial Bank & $\begin{array}{c}0.103 \\
(0.037)\end{array}$ & $\begin{array}{c}0.047 \\
(0.034)\end{array}$ \\
\hline
\end{tabular}

Note: Each row in this table reports the results from a separate regression. The dependent variables are the log of assets in 1997 and whether the household has a savings account in 1997 . The omitted category is that the institution is located more than $10 \mathrm{~km}$ from the village. In addition to the variables reported in the table, the regressions also include gender, a quadratic in age, and education of the husband and of the wife, and controls for the 1997 family composition similar to the ones in Table II. All standard errors are robust to heteroskedasticity and adjusted for clustering of the observations into enumeration areas.

While these results are consistent with the hypothesis that access to financial institutions helps families save, we are unable to ascribe a causal interpretation to these results. We are concerned that the financial institutions are more likely to locate in wealthier areas than in poorer areas. In this case, we would be confounding the financial institution's decision of where to locate with its effect on savings and wealth accumulation. To investigate this concern, we examine the regressed financial institutions' distance from the households against wage rates. Because actual wage rates may be endogenous to banking proximity, and are available only for those employed in the formal sector, we use the predicted wage based on age, education, and location. ${ }^{4}$ Table $\mathrm{V}$ reports the results of those regressions.

Neither commercial banks nor microfinance institutions are significantly more likely to locate in areas with high predicted wage rates. While this result may be expected for the microfinance institutions, it is more surprising for commercial banks. As expected, commercial banks and BRI are more distant from rural than from urban households. These results lend some credibility to our assumption that location of credit institutions is not endogenous.

\subsection{Access and insuring health shocks}

We now assess the effect of geographical proximity to financial institutions on the ability of households to insure consumption against illness. We do so by adding the interactions between the change in ADLs and dummies for the distance to financial institutions. We estimate a separate model for each financial institution, including all the controls for age and education of the head of the household, age, and

${ }^{4}$ We use the predicted wages described above in the section on the relative effect of husband and wife health. 
Table V. Regressions of distance of bank from household

\begin{tabular}{lccc}
\hline & Commercial banks & BRI & BKD \\
\hline Head's predicted wage & -0.663 & -0.392 & -0.265 \\
& $(0.954)$ & $(0.483)$ & $(0.175)$ \\
Rural & 8.339 & 4.999 & 0.215 \\
& $(1.642)$ & $(0.693)$ & $(0.269)$ \\
Constant & 7.860 & 3.938 & $(1.975$ \\
& $(6.583)$ & $(3.266)$ & $(1.230)$ \\
$R^{2}$ & 0.32 & 0.26 & 0.09 \\
Sample size & 3280 & 1737 & 1125 \\
\hline
\end{tabular}

Note: Each column reports the results from a separate regression whose dependent variable is the distance in kilometers of the financial institution from the household in 1997. The regression also includes province fixed effects. All standard errors are robust to heteroskedasticity and adjusted for clustering of the observations into enumeration areas.

Table VI. Effect of distance to savings/credit institutions dependent variable is the $\Delta$ in log monthly per capita consumption

\begin{tabular}{|c|c|c|c|}
\hline & BRI & BKD & Commercial Bank \\
\hline (Sum of $\Delta$ in wage-weighted ADL indices $) \times($ institution is $0-1 \mathrm{~km}$ from village $=1)$ & $\begin{array}{l}0.011 \\
(0.191)\end{array}$ & $\begin{array}{l}0.520 \\
(0.182)\end{array}$ & $\begin{array}{l}0.173 \\
(0.284)\end{array}$ \\
\hline (Sum of $\Delta$ in wage-weighted ADL indices) $\times($ institution is $2-10 \mathrm{~km}$ from village $=1)$ & $\begin{array}{l}0.515 \\
(0.154)\end{array}$ & $\begin{array}{l}0.589 \\
(0.624)\end{array}$ & $\begin{array}{l}0.365 \\
(0.207)\end{array}$ \\
\hline (Sum of $\Delta$ in wage-weighted ADL indices) $\times($ institution is $>10 \mathrm{~km}$ from village $=1)$ & $\begin{array}{l}0.679 \\
(0.305)\end{array}$ & $\begin{array}{l}1.494 \\
(1.163)\end{array}$ & $\begin{array}{l}0.861 \\
(0.376)\end{array}$ \\
\hline
\end{tabular}

Note: Each column is a separate regression. The regression also includes the variables in Table II and two dummies to control for distance from credit institution. Standard errors are in parentheses. For each regression, equality of the three coefficients can be rejected at the $1 \%$ level.

education of the spouse, family composition, rural status, as well as two dummies for distance from the credit institution.

For households located within $1 \mathrm{~km}$ of a financial institution, health shocks have substantively and statistically significantly smaller effects on consumption than for households living $10 \mathrm{~km}$ or more from a financial institution (Table VI).

While all of the models suggest that households situated closer to financial institutions are better able to insure consumption against health shocks, the most convincing evidence is from the model with distance to BRI branches. As we saw above, BRIs are widely dispersed throughout the nation, with no concentration in more advantaged areas. For communities with a BRI branch, health shocks have no effect on consumption. In contrast, the loss of an ADL in areas not served by a BRI branch lowers consumption by $2-3 \%$.

Results with BKD (the almost-universal community cooperatives) are in the same direction as BRI but not statistically significant. BKD may do less than BRI to help families self-insure because it provides only small loans and lacks savings accounts. Alternatively, the results may lose statistical significance solely because BKD is so universal (covering $92 \%$ of communities) that statistical power is low.

We perform a number of robustness checks. First, results are similar if we control for the region with 300-enumeration area fixed effects instead of dummies for each province interacted with rural versus urban. As expected, with fewer degrees of freedom, standard errors increase slightly. Second, as noted above, results are similar if we include single-parent households. Third, one possible explanation for our results is that communities without banks are remote in general, so health shocks matter more. On the one hand, we have seen that BRI branches are not located in particularly advantaged or disadvantaged places. At the same time, they are more likely to be in district capitals. (The 300 districts in Indonesia are a bit more important than counties in the United States.) Controlling for distance to the district capital 
and its square does not alter the basic results, although standard errors increase and some results lose statistical significance. Finally, urban areas have thicker labor markets and more health-care providers, as well as more nearby financial institutions. Thus, we repeated the main test (Table III) controlling for the interaction urban $\times$ changes in ADLs. Results were very similar.

\section{CONCLUSIONS}

Nobody would be surprised at the result that families in the United States without a checking or savings account are unusually vulnerable to unfavorable health shocks. Similarly, nobody would be surprised that families that live far from a financial institution in a less urban and less industrialized nation such as Indonesia are less likely to have a savings account. Nevertheless, it is somewhat surprising how important access to financial institutions is in helping families deal with adverse health shocks. In this study, families that live far from a financial institution will suffer greater losses in consumption than will families living nearer the institutions. This result does not appear to be due to financial institutions locating themselves near the advantaged, as the microfinance provider BRI does not follow that pattern.

Several tests indicate that these correlations are probably not due to state-dependent preferences where people who become disabled prefer to consume less. If we see low consumption due to lower desire to eat, for example, the effect should be strongest for those who engage in physical labor. In contrast, we find effects for both those engaged in work with and without physical labor before the health shock. Moreover, we see no effects of health on consumption for those with high initial assets and those living near a financial institution. These results are consistent with self-insurance, not statedependent preferences. Similarly, the possibility of an omitted variable reducing both health and consumption would not explain why the correlations between health changes and consumption changes are so much lower near financial institutions.

Traditionally, governments interested in helping families prepare for adverse shocks have used subsidies, mandates, or direct government provision of health insurance and disability insurance. On the one hand, no policies should be based on a single study. On the other hand, if these findings are replicated in other settings, the policy implication is clear: Government promotion of microfinance and microsavings programs can be useful in addition to tools traditionally used.

The good news is that BRI's small lending and deposit program apparently does not require much subsidy (or perhaps any, as argued by Yaron et al., 1998), in spite of the diseconomies of scale from handling very small deposits and loans. At the same time, most microfinance programs do not cover all their costs. A small subsidy to help cover the fixed cost of enrolling each household may help to expand the share of households that have financial assets. These assets, in turn, may be quite useful in protecting families against the adverse effects of almost-inevitable reductions in health, employment, or harvests or other shocks to income and needs.

\section{APPENDIX A: STATE DEPENDENCE TESTS}

It seems unlikely that state dependence could account for the very large family consumption effects that we find, given that we are measuring illness to only one of the adults and that the average family size in our data is almost five. For example, if consumption is distributed equally across family members, a movement in intermediate ADLs from 1 to 0 would have to lower the husband's consumption by roughly $100 \%$ to explain our result.

Of course, due to differential economies of scale and consumption patterns within the household, the head may account for more than $20 \%$ of family consumption; thus, this result cannot conclusively refute state dependence as an explanation for our findings. 
Moreover, the illness of the head may be correlated with illness of other family members so that the large percentage effect on family consumption reflects family-wide changes in tastes. This latter hypothesis is tested by including in our model changes in the ADLs of the wife. In fact, when we do so, we find that the coefficient on change for the head's ADLs actually slightly increases. This is to be expected as there is a very low correlation between the illnesses of the head and the wife (correlation $=0.10$ ). While the magnitude of the estimated effect of ADL changes suggests that state dependence is not the main cause of our results, we propose three more rigorous tests in this section to demonstrate that state dependence is not driving our findings.

\section{A.1. The relative effect of husband and wife health}

Our first test for distinguishing state dependence extends the results just presented to assess whether the health of the husband and the wife affects consumption in proportion to the amount they contribute to family income. If there is state dependence, then health should affect consumption regardless of the amount each individual works for pay. If the results are due to lower incomes, not state dependence, then health should affect consumption in proportion to the individual's contribution to family earnings.

We examine this hypothesis by testing whether the change in the husband's ADL index has the same effect on change in consumption as the change in the wife's ADL index when weighted by their relative contribution to income. We use predicted male and female wages adjusted for age, education, and location (province interacted with rural or urban) to measure the husband's and wife's contribution to full income. The predicted wages are constructed based on regressions using the 1993 SAKERNAS Labor Force survey, which is a nationally representative survey of over 40000 households. The sexspecific regressions include age, education, and location (province interacted with rural versus urban location). The predicted wage from this regression is matched to all persons, regardless of whether or not they work in the market.

The valuation of nonmarket work at the market wage is only appropriate if labor markets clear. This assumption is supported for Indonesia by Pitt and Rosenzweig (1985) and Benjamin (1992). In any case, we use wages solely as weights in averaging male and female health shocks. Results are robust to simple averages or to including male and female health shocks separately.

Model 1 in Table AI reports the results when the change in wage-weighted ADL indices is used in place of the change in unweighted indices. Recall that the estimated coefficient on the change in the

Table AI. State dependence tests

\begin{tabular}{|c|c|c|c|c|c|}
\hline & Model 1 & Model 2 & Model 3 & Model 4 & Model 5 \\
\hline$\Delta$ in husband's wage-weighted ADL index & $\begin{array}{c}0.367 \\
(0.164)\end{array}$ & & $\begin{array}{c}0.282 \\
(0.281)\end{array}$ & & \\
\hline$\Delta$ in wife's wage-weighted ADL index & $\begin{array}{c}0.382 \\
(0.137)\end{array}$ & & $\begin{array}{c}0.339 \\
(0.152)\end{array}$ & & \\
\hline$\Delta$ in sum of husband and wife's weighted ADL indexes & & $\begin{array}{c}0.376 \\
(0.100)\end{array}$ & & $\begin{array}{c}0.474 \\
(0.115)\end{array}$ & $\begin{array}{c}0.392 \\
(0.103)\end{array}$ \\
\hline$\Delta$ in husband's weighted ADL $\times$ husband had a physical labor job in 1993 & & & $\begin{array}{c}-0.009 \\
(0.307)\end{array}$ & & \\
\hline$\Delta$ in wife $\mathrm{ADL} \times$ wife had a physical labor job in 1993 & & & $\begin{array}{c}-0.071 \\
(0.189)\end{array}$ & & \\
\hline$\Delta$ in sum of weighted ADL $\times$ highest 1993 asset quartile $(=1)$ & & & & $\begin{array}{c}-0.404 \\
(0.228)\end{array}$ & \\
\hline$\Delta$ in sum of weighted ADL index $\times 1993$ savings/consumption & & & & & $\begin{array}{c}-0.048 \\
(0.023)\end{array}$ \\
\hline
\end{tabular}

Note: Each column reports the results from a separate regression whose dependent variable is the $\Delta$ in log monthly per capita consumption. In addition to the variables reported in the table, the regressions also include all of the variables used in the models reported in Table II. Models 4 and 5 have the main effect on asset quartile (Model 4) or savings/consumption 1993 (Model 5). Model 3 uses observations only for which the husband or wife was working for pay in 1993. Sample size 3281. 
husband's unweighted ADL index is about $25 \%$ larger than the wife's estimated coefficient. In contrast, the coefficient on the change in the wage-weighted husband's ADL index is almost identical to the coefficient on the change in the wife's wage-weighted ADL index. Weighting by the predicted wage moves the coefficients closer together. The results are similar if the weights are derived from 1993 imputed earnings (equal to 1993 actual hours from the IFLS times imputed wages from the SAKERNAS) instead of imputed hourly wages. The fact that health shocks weighted by relative earnings affect consumption in the same way suggests that health is operating through the budget constraint, not through state-dependent preferences.

As a benchmark for later analyses, Model 2 reports the coefficient on the sum of the changes of the wage-weighted husband's and wife's ADL indices. Consistent with the results above, each loss of 1 ADL by the husband or 1.25 ADL decline by the wife reduces consumption per capita by about 2 .

\section{A.2. Physical laborers versus nonphysical laborers}

The assumption underlying our discussion is that illness affects consumption by lowering the earning potential of workers. Alternatively, state dependence acting through illness should reduce the food consumption of individuals who work in physically demanding jobs more than those working in nonphysical labor jobs. Intuitively, a disability lowers the calorie needs of someone who was harvesting crops but has less effect on a shopkeeper or office worker. Thus, a test of our view versus state dependence is to consider the effects of illness on physical laborers relative to nonphysical laborers.

To test this hypothesis, we interact the change in the wage-weighted ADL indices with whether the person had a physical labor job in 1993 - the base year (Model 3). We define physically demanding jobs as laborers in construction, agriculture, and other occupations that require physical labor. The sample for this analysis is restricted to households in which the husband was working at least $20 \mathrm{~h}$ per week in 1993.

The estimated interaction is small and insignificant for both the husband and wife. That is, the reduction in consumption is not largest for those performing physically demanding tasks in 1993, in contrast to the hypothesis that health effects operate on consumption by reducing the demand for food. (Or, in other words, we provide no evidence that state dependence is important.)

If state dependence due to lower caloric demand after illness were important, we would expect to see food consumption declining more rapidly than nonfood consumption after a decline in health. (We thank an anonymous referee for this observation.) In fact, the decline of food and nonfood consumption is statistically indistinguishable (with a larger point estimate on the nonfood decline).

\section{A.3. Self-insurance}

Our third test for state dependence is to assess how our effect varies with the ability of families to selfinsure. If our results are due to inadequate insurance, families that are better able to self-insure should see a smaller effect of illness on consumption. Thus, a reduction in the labor supply or increase in medical-care expenditures should not reduce consumption much for families with high assets and savings in the first period (1993). However, there is no reason why state dependence should be smaller for families better able to self-insure.

Thus, if the effect of illness is much larger for poorly self-insured families, it suggests that these effects are operating through the budget constraint and not through state dependence. Our test therefore consists of including an interaction of illness with the indicator for ability to self-insure. A negative interaction would suggest that having self-insurance mitigates the effect of health shocks, which would be consistent with our hypothesis of imperfect insurance but inconsistent with state dependence. Morduch (1995) also discusses self-insurance as a means to maintain consumption. Our measures of self-insurance are family assets and savings. 
We investigate this proposition in Models 4 and 5 in Table AI. In Model 4, we interact the change in the sum of the wage-weighted ADLs with whether the household was in the top quarter of the asset distribution in 1993. Assets are measured with substantial error and have substantial outliers. Thus, we use quartiles in the asset distribution. Assets include the value of land, jewelry, cattle, cars, tractors, dwellings, and savings. In 1993, assets were $40 \%$ of household consumption for the bottom quartile, rising to 12.8 times consumption for the top quartile. The interaction is negative and significant. Moreover, the estimated value of interaction completely offsets the main effect, suggesting that families in the top quarter of the asset distribution are able to fully insure consumption against illness. In Model 5, we interact the change in ADLs with another measure of baseline wealth - savings divided by consumption in 1993. Again, the interaction is negative and significant, implying that those households that have more savings relative to consumption are better able to insure consumption against illness shocks. The fact that there are sizable and significant negative interactions with baseline wealth and savings measures is consistent with our interpretation of the ADL change as measuring a shock to the budget constraint.

Another possibility is that low food consumption reduces health. In results not shown we reran the regressions of Table II on nonfood consumption. Coefficients on ADL changes were larger and more statistically significant.

To summarize, we find that health shocks to both the husband and the wife matter in proportion to their contribution to family earnings, that the effects of health shocks are the same for physical and nonphysical laborers, and that families with significant assets are unaffected by health shocks. Taken together, these findings strongly refute the contention of state dependence.

\section{ACKNOWLEDGEMENTS}

The authors have no financial or other connection to any organization examined in this article. As this study uses only existing data, no approval by any committee for the protection of human subjects was sought or awarded. We appreciate comments from seminar participants at UCLA and UC, Berkeley as well as several referees. Remaining errors are the sole responsibility of the authors.

\section{REFERENCES}

Andrews G, Esterman A, Braunack-Mayer A, Rungie C. 1986. Aging in the Western Pacific. World Health Organization: Manila.

Asian Development Bank. 1997. Asian Development Outlook 1996 and 1997. Asian Development Bank: Manila.

Attanasio O, Ríos-Rull J-V. 2000. Consumption smoothing in island economies: can public insurance reduce welfare? European Economic Review 44(7): 1225-1258.

Benjamin D. 1992. Household composition, labor markets, and labor demand: testing for separation in agricultural household models. Econometrica 60(2): 287-322.

Cochrane JH. 1991. A simple test of consumption. Insurance Journal of Political Economy 99(5): 957-976.

Deaton A. 1992. Understanding Consumption. Clarendon Press: Oxford.

Deaton A. 1994. The Analysis of Household Surveys: Microeconometric Analysis for Development Policy. World Bank: Monograph, Washington, DC.

Fafchamps M, Udry C, Czukas K. 1998. Drought and saving in West Africa: are livestock a buffer stock? Journal of Development Economics 55(2): 273-305.

Frankenberg E, Karoly L, Gertler P, Peterson C, Wesley D. 1995. The 1993 Indonesian Family Life Survey: overview and field report. $D R U-1195$, RAND, Santa Monica, CA.

Frankenberg E, Thomas D. 2000. The Indonesia Family Life Survey (IFLS): study design and results from Waves 1 and 2. $D R U-2238 / 1-N I A / N I C H D$, RAND, Santa Monica, CA.

Gertler P, Gruber J. 2002. Insuring consumption against illness. American Economic Review 92(1): 51-70. 
Guralnik J, Branch L, Cummings S, Curb J. 1989. Physical performance measures in aging research. Journal of Gerontology 44(5): 141-146.

Harrower S, Hoddinott J. 2004. Consumption smoothing and vulnerability in the zone lacustre, Mali. Food Consumption and Nutrition Division Discussion Paper 175, International Food Policy Research Institute, Washington, DC.

Jacoby HG, Skoufias E. 1997. Risk, financial markets, and human capital in a developing country [available from http://links.jstor.org/sici?sici = 0034-6527\%28199707\%2964\%3A3\%3C311\%3ARFMAHC\%3E2.0.CO\%3B2N]. Review of Economic Studies 64(3): 311-335.

Jalan J, Ravallion M. 1999. Are the poor less well insured? Evidence on vulnerability to income risk in rural China. Journal of Development Economics Volume 58 (1): 61-81.

Ju A, Jones G. 1989. Aging in ASEAN and its Socio-Economic Consequences. Institute of South Asian Studies: Singapore.

Kochar A. 1995. Explaining household vulnerability to idiosyncratic income shocks. American Economic Review 85: $159-164$.

Morduch J. 1995. Income insuring and consumption insuring. Journal of Economic Perspectives 9 (Summer Issue): $103-114$.

Morduch J. 1999. Between the market and state: can informal insurance patch the safety net? The World Bank Research Observer 14(2): 187-207.

Pitt MM, Rosenzweig MR. 1985. Health and nutrient consumption across and within farm households. Review of Economics \& Statistics 67(2): 212-223.

Robinson MS. 2001. The Microfinance Revolution: Sustainable Finance for the Poor. World Bank: Washington,DC.

Robinson MS. 2002. The Microfinance Revolution: Lessons from Indonesia [Available from http://wwwwds.worldbank.org/servlet/WDSContentServer/WDSP/IB/2002/08/27/000094946_0208030401020/Rendered/ INDEX/multi0page.txt]. World Bank: Washington, DC.

Rosenzweig MR, Wolpin KI. 1993. Credit market constraints, consumption smoothing, and the accumulation of durable production assets in low-income countries: investments in bullocks in India. Journal of Political Economy 101(2): 223-244.

Skoufias E, Quisumbing AR. 2005. Consumption insurance and vulnerability to poverty: a synthesis of the evidence from Bangladesh, Ethiopia, Mali, Mexico and Russia [available from http://taylorandfrancis.metapress.com/ openurl.asp?genre $=$ article\&issn $=0957-8811 \&$ volume $=17 \&$ issue $=1 \&$ spage $=24]$. European Journal of Development Research 17(1): 24-58.

Stewert A, Ware J, Brook R, Davies-Avery A et al. 1990. Measurement of Adult Health Status: Physical Health in Terms Functional Status. Harvard University Press: Cambridge.

Strauss J, Gertler P, Rahman O, Fox K. 1993. Gender and life-cycle differentials in the patterns and determinants of adult health. Journal Of Human Resources 28: 791-837.

Thomas D, Frankenberg E, Smith JP. 2001. Lost but not forgotten: attrition and follow-up in the Indonesia family life survey [available from http://links.jstor.org/sici?sici $=0022-166 \mathrm{X} \% 28200122 \% 2936 \% 3 \mathrm{~A} 3 \% 3 \mathrm{C} 556 \%$ 3ALBNFAA \%3E2.0.CO\%3B2-1]. Journal of Human Resources 36(3): 556-592.

Townsend RM. 1994. Risk and insurance in village India. Econometrica 62(3): 539-591.

Ware J, Davies-Avery A, Brook R. 1980. Conceptualization and Measurement of Health Status for Adults in the Health Insurance Study, Analysis of Relationships among Health Status Measures. R-1987/6-HEW. Vol. 4. RAND: Santa Monica, CA.

Yaron J, McDonald B, Charitonenko S. 1998. Promoting efficient rural financial intermediation. World Bank Research Observer 13(2): 147-170. 